\title{
KINETIC PARAMETERS OF POLYREACTIVE IMMUNOGLOBULINS INTERACTION WITH ANTIGENS IN THE PRESENCE OF PROTAMINE
}

\author{
S. A. BOBROVNIK, M. O. DEMCHENKO, S. V. KOMISARENKO \\ Palladin Institute of Biochemistry, National Academy of Sciences of Ukraine, Kyiv; \\ e-mail:s-bobrov@bk.ru
}

The discovered earlier phenomenon of the enhancment of polyreactive immunoglobulines (PRIGs) binding to antigens in the presence of protamine and Tween 20 was investigated in more details. The comparative analysis of PRIGs reaction dynamics with immobilized antigen was provided. In addition, the rate constants for the reaction and the affinity constants of PRIGs-antigen binding in the presence or absence of optimal protamine concentration were determined. The rate constant of PRIGs-antigen reaction did not increase in the presence of protamine optimal concentration and was even reduced approximately twice. However, in the presence of protamine the concentration of reactive PRIGs molecules, that were able to interact with antigen, increased approximately 30 times, and this led to strong reaction rate increase. Protamine also influenced the affinity constant of PRIGs-antigen binding, which increased approximately three times. The suggestion was made that such protamine effect was due to its influence on the PRIGs molecules special structure, and, as a result of the conformational change PRIGs became able to bind more effectively to the antigens.

Key words: polyreactive immunoglobulines, antigens, protamine, rate constant, affinity constant.

$\mathrm{W}$ e have shown earlier [1, 2], that PRIGs binding to antigens strongly depended (resulted in increase or decrease) on the properties of the incubation medium. For example, the presence in the incubation media either Tween 20 or 1-anilino-8-naphthalenesulfonate significantly inhibited PRIGs binding to antigens. In contrast, several proteins, which had positive charge at neutral $\mathrm{pH}$ in aqueous solutions, were able to increase PRIGs reactivity and stimulate PRIGs-antigen interaction. Some of such proteins were salmon caviar protamine and hen egg lysozyme. As we have found, the protamine much stronger increased PRIGs interaction with antigens than lysozyme [1, 2]. In addition, it was determined, that albeit Tween 20 weakened the PRIGs interaction with antigens. We could observe the opposite effect in the presence of protamine together with protamine Tween 20 increased the PRIGs binding to antigens more efficiently, than the same concentration of protamine in the absence of Tween 20.

Since more detailed study of this effect could shed light on the details of the mechanism of PRIGs interaction with antigens, we decided to investigate how protamine optimal dozes influenced the rate constant of PRIGs binding to the immobilized on the plate antigen in the presence of Tween 20, as well as on the affinity of PRIGs binding to the antigen in solution. The results of this investigation are described in this paper.

\section{Materials and Methods}

Antigen, PRIGs, and ELISA. We used bovine serum albumin (BSA) from Sigma, USA as an antigen. Protamine from the salmon caviar was from Sigma, USA. Mice normal serum was used as a pool of PRIGs. In our preliminary investigations it was shown that this serum had high level of PRIGs activity (not published).

The quantity of immunoglobulins bound to the absorbed antigen on the plate in different conditions was determined by enzyme-linked immunosorbent assay (ELISA). For this purpose, the plates with PRIGs bound to immobilized antigen were incubated with goat anti-mouse IgG antibodies conjugated with peroxidase (Sigma, USA) during $60 \mathrm{~min}$ at $4{ }^{\circ} \mathrm{C}$. The unbound conjugates were carefully washed away, and peroxidase substrate - the solution of orthophenilen diamine $(1 \mathrm{mg} / \mathrm{ml})$ in $0.01 \mathrm{M}$ phosphate buffer, $\mathrm{pH} 5.0$ and $0.003 \% \mathrm{H}_{2} \mathrm{O}_{2}$ solution were added. 
The reaction was stopped after colour developing, by adding of $0.05 \mathrm{ml} 2 \mathrm{M}$ sulfuric acid per well, and optical density was measured by microphotocolorimeter ELX800 (BIO-TEK) at $490 \mathrm{~nm}$.

PRIGs interaction with BSA as an antigen, either in a solution or being immobilized on microplates, was studied. As an incubation media either the physiological solution of $\mathrm{NaCl}$ buffered with phosphate buffer, $\mathrm{pH} 7.2$ plus $0.01 \%$ Tween 20 (TBS), or the same TBS solution with adding $0.2 \mathrm{mg} / \mathrm{ml}$ protamine were used. The investigations of the kinetics of PRIGs binding to the immobilized BSA were carried out either in TBS or in TBS + protamine. PRIGs solutions in TBS or in TBS + protamine were added to the plate wells at different intervals at room temperature. After the incubation the plates were thoroughly washed and the quantity of PRIGs bound to the immobilized antigen was determined by ELISA as described above.

To estimate the affinity constant for PRIGs BSA interaction, their solutions in TBS or in TBS + protamine were mixed 1:1 together and incubated for 60 minutes at room temperature. Then all samples of PRIGs-BSA mixtures were added to the plate wells with immobilized BSA in order to determine the quantity of free PRIGs in each sample, which depended on the concentration of BSA in the samples. It should be noted, that in case of using TBS as the solvent, dilutions of mice serum, used as a PRIGs source, were $1: 10$ 000, but when using TBS + protamine the dilution of serum was 10 times higher, namely $1: 100000$.

In order to bind BSA (as an antigen) to the plate wells we used a method we had developed earlier [3]. In short, $0.1 \mathrm{ml}$ of the solution of BSA (2-3 mkg/ $\mathrm{ml}$ ) in $1 \%$ solution of $\mathrm{NH}_{4} \mathrm{HCO}_{3}+0.01 \% \mathrm{NaN}_{3}$ were added to each well and dried on plates at $37^{\circ} \mathrm{C}$. This method of antigen sorption on plates was approximately 10 times more effective than the traditional method of antigen immobilization when solution of antigen was incubated in plates at 4 or at $37^{\circ} \mathrm{C}$ [3]. So, firstly, our method allows us to use ten times lower antigen concentration for plates covering. This method of antigen immobilization by drying antigen solution provided more efficient denaturation of immobilized antigens than by antigen adsorption using traditional method. As far as PRIGs bind more effectively to denatured antigens, our method of antigen immobilization is more suitable for PRIGs investigation.

Theory of PRIGs-antigen kinetics and equilibrium investigations. Assuming, that PRIGs bind to immobilized antigen approximately in a similar way as specific antibodies do, one may consider that this reaction is practically irreversible and that it should follow according to the scheme:

$$
R \rightarrow P \text {, }
$$

where $R$ is PRIGs in a solution, $P$ - is the reaction product, that is PRIGs bound to immobilized antigen on microplate. In this case, the dynamics of PRIGs binding to microplate is described by the following equation:

$$
P_{i}=P_{\infty}\left(1-\mathrm{e}^{-k t}\right),
$$

where $k-$ is the rate constant of the reaction, $P_{i}-$ quantity of the reagent bound to immobilized antigen during reaction time $t_{i}, P_{\infty}$ - quantity of reagent, bound to immobilized antigen at reaction time $t=\infty$, namely, when the irreversible reaction became totally finished.

Inasmuch as equation (2) is irrational, for this reason it has no analytical solution in general case for calculation of two unknowns $k$ and $P_{\infty}$. For this reason, Guggenheim has proposed graphical method for its solution [4], which was later improved by Kazdy et al. [5], and later by Swinbourne [6].

In contrast to the mentioned graphical methods, we suggested the analytical solution of equation (2) for a special case, namely when $t_{2 i}=2 t_{i}$ [7]. It was shown that the unknown variables $k$ and $P_{\infty}$ in equation (2) might be obtained by using the curve of dynamic receptor binding as follows. At first using the data of experimental kinetic curve displaying dependence of quantity of bound reagent $P_{i}$, on time $t_{i}$, the total quantity of reaction product may be calculated $P_{\infty}$ by equation (3):

$$
P_{\infty}=\frac{P_{i}^{2}}{2 P_{i}-P_{2 i}},
$$

where $P_{i}$ - quantity of receptor binding for reaction time $t_{i}, P_{2 i}$ - quantity of bound receptor at time $t_{2 i}$, when the necessary condition is $t_{2 i}=2 t_{i}$.

It should be noted that the quantities $P_{\infty}, P_{\mathrm{i}}$ and $P_{2 \mathrm{i}}$ might be expressed not only in molar concentrations but also using any quantities proportional to them. In the course of using ELISA for these calculations it is convenient to use the optical density of dyes developed in microplate wells, which in experiment must be proportional to the quantity of PRIGs bound to plate.

After this, knowing the value of $P_{\infty}$, one may calculate also the reaction rate constant, $k$, by the following equation: 


$$
k=\frac{1}{t_{i}} \ln \frac{P_{\infty}}{P_{\infty}-P_{i}} .
$$

It is important to note, that the values of $P_{\infty}$ may be calculated more precisely, if we determine it instead of two measurements values of $t_{i}, P_{i}$ and $t_{2 i}, P_{2 i}$ but by finding a tangent of the slope angle of liner dependence sized $P_{i}^{2}$ on $2 P_{i}-P_{2 i}$ as it follows in accordance to equation (3). By the same way, $k$ may be calculated more precisely if we determine a tangent of the slope angle of liner dependence $\ln \left(P_{\infty} /\left(P_{\infty}-P_{i}\right)\right)$ on $t_{i}$ in order to find the value of $k$ in accordance with equation (4).

For estimating the equilibrium constant for interaction of antibodies with antigens by the method of ELISA the ideas of the following methods were used $[8,9]$. In addition, these methods were improved by us [10], and a new method was proposed for estimating affinity of two antibodies, which are found in the studied mixture [11]. The use of our method is very important, if the affinities of two studied antibodies differ greatly from each other. Thus, we used this method to estimate equilibrium constants for interaction of PRIGs with antigen in both media indicated above, i.e. in TBS or in TBS + protamine. In addition, our method allows determining the relation between concentrations of high affinity and low affinity reagents in the studied samples [11].

For this purpose the curves of the dependences of free PRIGs concentration in solution with different concentration of antigen when the equilibrium of reaction is established, were compared with theoretical curves for similar interaction of the reagents according to equation (5) [11] and the quantities of both equilibrium constant for high and low affinity PRIGs were calculated by the method of linear regression using computer program Origin 9. The relations between concentrations of high and low affinity PRIGs in TBS or in TBS + protamine were also determined as relations between the values of $A_{01}$ и $A_{02}$ :

$$
A_{i}=\frac{A_{01}\left(1+2 l_{i} K_{a 1}\right)}{\left(1+l_{i} K_{a 1}\right)^{2}}+\frac{A_{02}\left(1+2 l_{i} K_{a 2}\right)}{\left(1+l_{i} K_{a 2}\right)^{2}},
$$

where $K_{\mathrm{a} 1}$ and $K_{\mathrm{a} 2}$ - affinity constants for high and low affinity PRIGs, $A_{01}$ and $A_{02}$ - the quantities which are proportional to the concentrations of high and low affinity PRIGs in investigated samples (when $l_{\mathrm{i}}=0$ ), $A_{\mathrm{i}}$ - the value, proportional to concentration of free PRIGs in investigated PRIGs-antigen mixture after achievement of equilibrium, if the concentration of antigen was $l_{i}$. The values $A_{i}, A_{01}$ and $A_{02}$ were introduced in units of optical density of microplates wells measured by ELISA; in our investigations they were proportional to the concentration of PRIGs, bound to immobilized antigen on the plate.

\section{Results and Discussion}

The kinetic curves of PRIGs binding to the immobilized antigen on the plate are presented in Fig. 1. One of the curves in Fig. 1 represents the binding of PRIGs in TBS and another one in TBS + $0.2 \mathrm{mg} / \mathrm{ml}$ of protamine. It is important to note, that in preliminary investigations we established that the reactivity of PRIGs in mixtures of TBS $+0.2 \mathrm{mg} /$ $\mathrm{ml}$ protamine is a minimum ten times higher than the reactivity of PRIGs in TBS [1]. Then for keeping an absolutely necessary condition of proportionality between optical density of wells, obtained by ELISA, and the concentration of PRIGs bound to immobilized antigen on the plate, the concentration of PRIGs in the samples with $0.2 \mathrm{mg} / \mathrm{ml}$ protamine was 10 times lower than in the samples without protamine.

As one may see in Fig. 1, in spite of the fact that PRIGs concentration in TBS + protamine was 10 times lower than in TBS without protamine, the amount of PRIGs bound to the plate in samples TBS + protamine was much higher, than in the samples where PRIGs were in TBS. The calculations of the unknown according to equation (2), i.e. of the amount of bound PRIGs (at $t=\infty$ ) in the

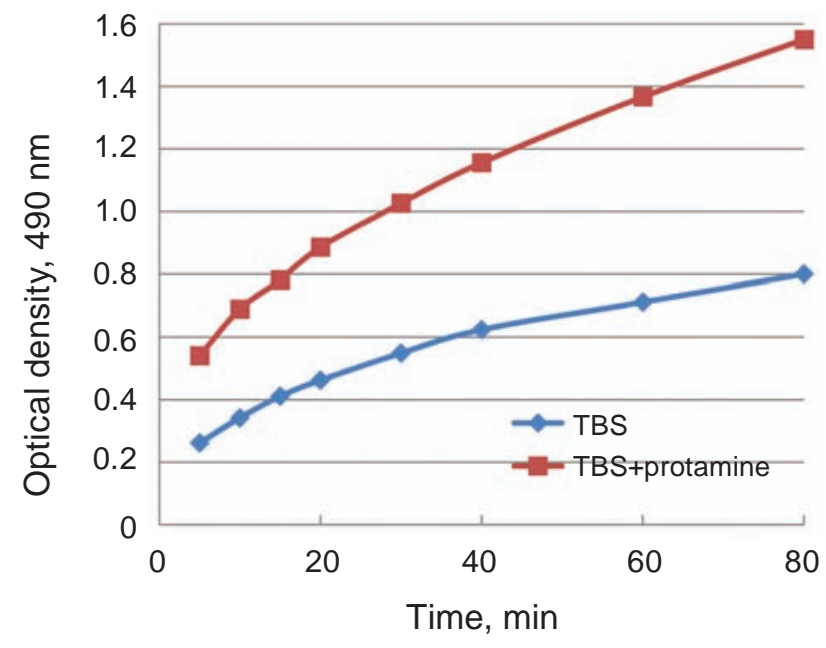

Fig. 1. Kinetic of PRIGs binding to BSA immobilized on plates either in solutions TBS or in TBS $+0.2 \mathrm{mg} /$ $\mathrm{ml}$ protamine 
units of optical density, $P_{\infty}$, are shown in Fig. 2 and Fig. 3. It was found that for samples PRIGs in TBS $P_{\infty}=1.1870$, and for samples PRIGs in TBS + protamine $P_{\infty}=3.3874$.

Thus, these data demonstrated that the concentration of reactive PRIGs molecules in the studied samples of PRIGs in TBS + protamine, (i.e. the values $P_{\infty}$ ) was almost three times higher than this value for the samples of PRIGs in TBS. In view of the fact that the PRIG samples in TBS + protamine were diluted ten times in comparison with the PRIGs samples in TBS, the quantity of PRIGs molecules, which were able to react with the antigen, increased almost 30 times, due to the presence of $0.2 \mathrm{mg} / \mathrm{ml}$ protamine in solutions.

In Fig. 4 the plots of dependence of the concentration of non-blocked PRIGs are presented in studied samples with different concentrations of blocking antigen, if those samples were found either in TBS or in TBS $+0.2 \mathrm{mg} / \mathrm{ml}$ protamine. From Fig. 4 we can see, that the process of nonspecific PRIGs blocking by antigen took place significantly more extensively, if in the mixtures of PRIGs and antigen in TBS the $0.2 \mathrm{mg} / \mathrm{ml}$ protamine was present. This fact showed convincingly, that the binding of PRIGs with antigen proceeds much more effectively, if protamine was present in PRIGs-antigen solution.

Using equation (5) the calculations of affinity constants, $K$, and the relation between quantities of high and low affinity PRIGs (values of $A_{01}$ and $A_{02}$ ) depending on the presence of protamine in solution, completely confirmed this conclusion. It turned out

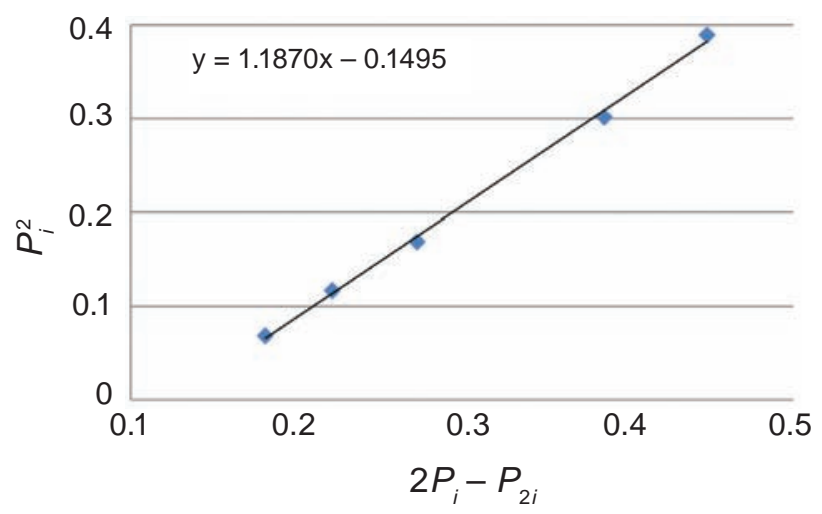

Fig. 2. Determination of $P_{\infty}$ values for PRIG in TBS using the data presented in Fig. 1 (cure below) and equation (3). The liner dependence of $P_{i}^{2}$ and $2 P_{i}^{-}$ $P_{2 i}$, and its equation are shown. Since tangent of the slope of this function according to equation (3), is $P_{\infty}$, then in this case $P_{\infty}=1.1870$

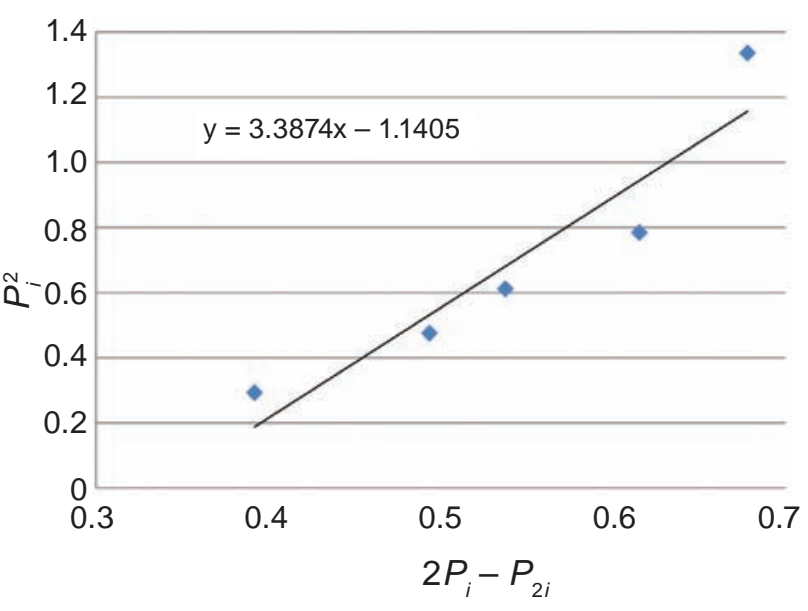

Fig. 3. Determination of $P_{\infty}$ values for PRIG in TBS $+0.2 \mathrm{mg} / \mathrm{ml}$ protamine using the data presented in Fig. 1 (cure upper) and equation (3). The liner dependence of $P_{i}^{2}$ or $2 P_{i}-P_{2 i}$, and its equation are shown. Since tangent of the slope of this function according to equation (3), is $P_{\infty}$, then in this case $P_{\infty}=3.3874$

that the affinity constant for PRIGs-antigen interaction in TBS, according to equation (5), were three times lower than that for the interaction of PRIGs with antigen, if these reagents were in the same solution, but with addition of $0.2 \mathrm{mg} / \mathrm{ml}$ protamine, i.e., $K_{a 1}=1.14 \cdot 10^{6} \mathrm{M}^{-1}$ and $K_{a 1}=3.47 \cdot 10^{6} \mathrm{M}^{-1}$, correspondently (Table). In addition, not only the absolute values of $A_{01}$ and $A_{02}$ were different significantly for the samples of PRIGs in the presence or in the absence of protamine, but also the relation between $A_{01}$ and $A_{02}$ differed substantially for both solutions.

As one may see from the Table, practically all PRIGs in the presence of $0.2 \mathrm{mg} / \mathrm{ml}$ protamine might be attributed to high affinity ones, because almost $93 \%$ of total amount belonged to the high affinity PRIGs. In the absence of protamine the affinity of PRIGs binding to antigen was not only three times lower, but also the quantity of high-affinity PRIGs was lower at least twice (almost 42\%), when lowaffinity PRIGs $\left(K_{a 2}=6.20 \cdot 10^{4} \mathrm{M}^{-1}\right)$ were in a larger part of all reactive PRIGs. On the contrary, in the presence of protamine only about $7 \%$ of PRIGs had very low affinity $\left(K_{a 2}=1.04 \cdot 10^{4} \mathrm{M}^{-1}\right)$, while approximately $93 \%$ of PRIGs had relatively high affinity $\left(K_{a 1}=3.47 \cdot 10^{6} \mathrm{M}^{-1}\right)$.

The analysis of the data obtained showed that the reactive ability of PRIGs regarding their interaction with antigens might be changed to a significant degree depending on the environment. Probably, 
The affinity constants $\left(K_{a l}\right.$ and $K_{a 2}$ ) for PRIGs samples either in TBS or in TBS $+0.2 \mathrm{mg} / \mathrm{ml}$ protamine, and the relations between amounts of high and low affinity PRIGS $\left(A_{01}\right.$ and $\left.A_{02}\right)$ in those solutions

\begin{tabular}{l|c|c|c|c|c}
\hline \multicolumn{1}{c|}{ Parameters } & $A_{01}$ & $K_{a 1}$ & $A_{02}$ & $K_{a 2}$ & $A_{01} /\left(A_{01}+A_{02}\right), \%$ \\
\hline TBS & 0.626 & $1.14 \cdot 10^{6} \mathrm{M}^{-1}$ & 0.880 & $6.20 \cdot 10^{4} \mathrm{M}^{-1}$ & 42 \\
TBS + protamine & 1.147 & $3.47 \cdot 10^{6} \mathrm{M}^{-1}$ & 0.090 & $1.04 \cdot 10^{4} \mathrm{M}^{-1}$ & 93 \\
\hline
\end{tabular}

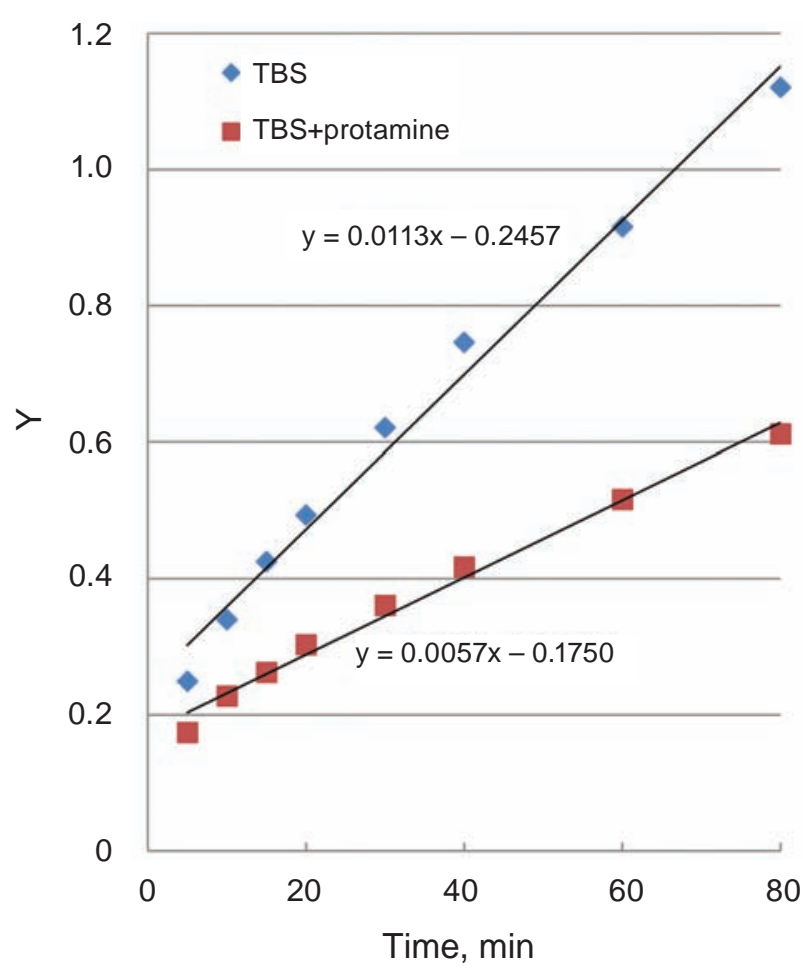

Fig. 4. Liner dependence between $Y=\ln \frac{P_{\infty}}{P_{\infty}-P_{i}}$ in time $t$ for binding kinetics of PRIGs with BSA presented in Fig. 1. Since according to equation (4), the tangents of the slope of liner dependence $\ln \frac{P_{\infty}}{P_{\infty}-P_{i}}$ on time $t$ are equal to reaction rate constants, for PRIGs binding with antigen in TBS solution the rate constant is $0.0113 \mathrm{~min}^{-1}$, and for PRIGs in TBS + protamine solution the rate constant is $0.0057 \mathrm{~min}^{-1}$, i.e. two times lower

such dependence may be connected to a relatively high plasticity of PRIGs molecules, which are able to change their conformation. Because of these properties, PRIGs molecules can expose hydrophobic sites on their surface and as a result of this PRIGs may become able to bind nonspecifically to various antigens. We suggested that due to molecular dynamics of PRIGs polypeptide chains, such hydrophobic sites might appear for a short time on the surface of Fv-

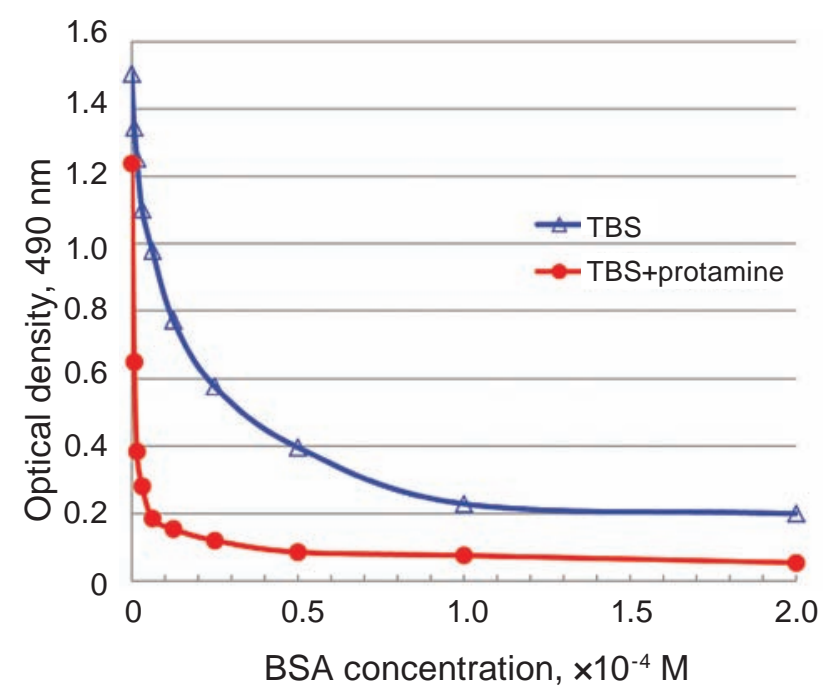

Fig. 5. Dependence of free PRIGs concentration on antigen concentration after the equilibrium of PRIG-antigen reaction in TBS or in TBS + protamine is achieved. These curves allow calculation the equilibrium binding constants of high-affinity and low-affinity, $K_{a 1}$ and $K_{a 2}$, and also the ratio of the concentrations of high-affinity and low-affinity PRIGs using equation (5) (see table)

regions of the Ig molecules and due to that PRIGs obtained the ability of nonspecific binding with antigens by hydrophobic interaction, as it was suggested by us earlier [12, 13].

In conclusion, it is necessary to stress that in contrast to specific antibodies, the PRIGs molecules may change their structure and acquire the properties to interact with antigens. If this is so, then the PRIGs ability to bind antigens changes in the process of PRIGs-antigen reaction because during the time "non-active" PRIGs molecules can transform into "active" molecules. Then the scheme (1), that describes the reaction of specific antibodies with antigen, may be hardly suitable for more complex process of PRIGs-antigens reaction. For these reasons the rate constants and the affinity constants for PRIGs interaction with BSA, which were found by as above, may not be exact ones and they are suitable 
only for relative comparisons between each other. The true scheme of PRIGs-antigen interactions may appear much more complex and in this case the calculations of kinetic parameters of this interaction, possibly, will require much more complex mathematic calculations.

\section{ЗМІНА КІНЕТИЧНИХ ПАРАМЕТРІВ ВЗАЕМОДІЇ ПОЛІРЕАКТИВНИХ ІМУНОГЛОБУЛІНІВ І3 АНТИГЕНАМИ В ПРИСУТНОСТІ ПРОТАМІНУ}

\author{
С. А. Бобровник, М. О. Демченко, \\ С. В. Комісаренко
}

Інститут біохімії ім. О. В. Палладіна

НАН України, Київ;

e-mail: s-bobrov@bk.ru

Відкритий нами раніше феномен підсилення реакції зв'язування поліреактивних імуноглобулінів (ПРІГ) із антигенами в присутності протаміну і Твіну 20 досліджено детальніше. Проведено порівняльній аналіз динаміки зв'язування ПРІГ з іммобілізованим антигеном, визначено константи швидкості реакції, а також константи афінності ПРІГ до антигену в присутності оптимальних доз протаміну i за його відсутності. Показано, що константа швидкості зв'язування ПРІГ 3 іммобілізованим антигеном у присутності оптимальних доз протаміну не збільшується, а навіть зменшується в два рази. Проте в присутності протаміну у 30 разів збільшується концентрація реакційноздатних молекул ПРІГ, за рахунок чого помітно збільшується швидкість взаємодії. Протамін впливає на константу афінності зв'язування ПРІГ із розчиненим антигеном i збільшує іï приблизно в три рази. Зроблено припущення, що подібний ефект протаміну пов'язаний з його впливом на структуру молекул ПРІГ, внаслідок чого вони змінюють свою конформацію і ефективніше зв'язуються з антигенами.

К л ю ч о в і с с о в а: поліреактивні імуноглобуліни, антигени, константа швидкості, константа рівноваги.

\section{ИЗМЕНЕНИЕ КИНЕТИЧЕСКИХ ПАРАМЕТРОВ ВЗАИМОДЕЙСТВИЯ ПОЛИРЕАКТИВНЫХ ИММУНОГЛОБУЛИНОВ С АНТИГЕНАМИ В ПРИСУТСТВИИ ПРОТАМИНА}

\author{
С. А. Бобровник, М. А. Демченко, \\ С. В. Комисаренко
}
Институт биохимии им. А. В. Палладина НАН Украины, Киев; e-mail: s-bobrov@bk.ru

Обнаруженный нами ранее феномен усиления реакции связывания полиреактивных иммуноглобулинов (ПРИГ) с антигенами в присутствии протамина и Твина 20 исследован более детально. Проведен сравнительный анализ динамики связывания ПРИГ с иммобилизованным антигеном, определены константы скорости реакции, а также константы аффинности ПРИГ к антигену в присутствии оптимальных доз протамина и в его отсутствии. Показано, что константа скорости связывания ПРИГ с иммобилизованным антигеном не увеличивается в присутствии оптимальной концентрации протамина, а даже снижается примерно в два раза. Зато в присутствии протамина примерно в 30 раз увеличивается концентрация реакционноспособных молекул ПРИГ, за счет чего заметно повышается скорость реакции взаимодействия. Протамин оказывает влияние на константу аффинности связывания ПРИГ с растворимым антигеном и повышает ее примерно в три раза. Сделано предположение, что подобный эффект протамина связан с его влиянием на структуру молекул ПРИГ, в результате чего они меняют конформацию и более эффективно связываются с антигенами.

К л ю ч е в ы е с с л в а: полиреактивные иммуноглобулины, антигены, константа скорости, константа равновесия 


\section{References}

1. Bobrovnik SA, Demchenko MA, Komisarenko SV. Interaction peculiarities of polyreactive immunoglobulins and various antigens. Ukr Biochem J. 2014; 86(1): 68-74. (In Russian).

2. Bobrovnik SA, Demchenko MA, Komisarenko SV. Fundamental differences between natural antibodies and polyreactive immunoglobulins. Ukr Biochem J. 2015; 87(5): 46-53.

3. Bobrovnik SA, Starodub NF. A new simple method of antigen immobilization on immunological plates. Immunology (Moscow), 1988; 9(5): 83-85. (In Russian).

4. Guggenheim E.A. On the determination of the velocity constant of a unimolecular reaction. Philos Mag. Ser VII, 1926; 2(9): 538-543.

5. Kazdy FJ, Jaz J, Bruylants A. Cinétique de L'action de L'acide Nitreux sur les Amides I. Méthode Générale. Bull Soc Chem Belg. 1958; 67: 687-706.

6. Swinbourne ES. Method for obtaining the rate coefficient and final concentration of a firstorder reaction. J Chem Soc. 1960; 2371-2372.

7. Bobrovnik SA. Determination of kinetic parameters for both reversible and irreversible first-order reactions. $J$ Biochem Biophys Methods. 1998; 37(1-2): 53-68.

8. Friguet B, Chaffotte AF, Djavadi-Ohaniance L, Goldberg ME. Measurements of the true affinity constant in solution of antigen-antibody complexes by enzyme-linked immunosorbent assay. J Immunol Methods. 1985; 77(2): 305-319.

9. Stevens FJ. Modification of an ELISA-based procedure for affinity determination: correction necessary for use with bivalent antibody. $\mathrm{Mol}$ Immunol. 1987;24(10): 1055-1060.

10. Bobrovnik SA. Determination of antibody affinity by ELISA. Theory. J Biochem Biophys Methods. 2003; 57(3): 213-236.

11. Stevens FJ, Bobrovnik SA. Deconvolution of antibody affinities and concentrations by nonlinear regression analysis of competitive ELISA data. J Immunol Methods. 2007; 328(1-2): 53-58.

12. Bobrovnik SA. Polyreactive immunoglobulins recognize hydrophobic parts of proteins. $U k r$ Biokhim Zhurn. 2001; 73(2): 116-122. (In Russian).

13. Bobrovnik SA. Mechanisms of interaction of polyreactive immunoglobulins and protein antigens. Ukr Biokhim Zhurn. 2002; 74(2): 3744. (In Russian).

Received 29.02.2016 